University of Windsor

Scholarship at UWindsor

$1-2006$

\title{
Entrepreneurial Charisma: A Key to Employee Identification?
}

Francine K. Schlosser

Odette School of Business, University of Windsor

Zelimir William Todorovic

Follow this and additional works at: https://scholar.uwindsor.ca/odettepub

Part of the Business Commons

\section{Recommended Citation}

Schlosser, Francine K. and Todorovic, Zelimir William. (2006). Entrepreneurial Charisma: A Key to Employee Identification?. Journal of Small Business and Entrepreneurship, 19 (1).

https://scholar.uwindsor.ca/odettepub/113

This Article is brought to you for free and open access by the Odette School of Business at Scholarship at UWindsor. It has been accepted for inclusion in Odette School of Business Publications by an authorized administrator of Scholarship at UWindsor. For more information, please contact scholarship@uwindsor.ca. 


\section{Entrepreneurial Charisma: A Key to Employee Identification?}

Citation: Schlosser, Francine K. and Todorovic, Z. William, Entrepreneurial Charisma: A Key to Employee Identification?, Journal of Small Business and Entrepreneurship, 19(1) January, 49-62, 2006.

Key Words: entrepreneur, entrepreneurial orientation, organizational identification, charisma, leadership 


\begin{abstract}
Entrepreneurial businesses are an important driver of modern day economies. A firm that adopts a strategy of calculated risks, and also demonstrates proactiveness and innovation reflects an entrepreneurial orientation (EO). In order to create an entrepreneurial orientation and associated performance outcomes, it is necessary to understand the role of individuals and the interpersonal processes that shape values, norms and behaviors. Incorporating research from social psychology literature, this study examines the effect of individual and organizational variables on employees who work for an entrepreneurial venture. A cross-sectional study of 78 employees of small Canadian businesses empirically demonstrates how an entrepreneurial strategic orientation and a charismatic leadership style encourage employees to identify with the entrepreneurial organization. Empirical results indicated that personality and strategic direction play an important part in creating value for the entrepreneurial firm.
\end{abstract}

\title{
Introduction
}

Entrepreneurial businesses are an important driver of modern day economies and represent $70 \%$ of the Gross National Product (GNP) in North America (National Governors Association, 2000b). A firm that adopts a strategy of calculated risks, and also demonstrates proactiveness and innovation reflects an entrepreneurial orientation (EO) (Miller, 1983; Morris \& Paul, 1987). Gazelles, or growing entrepreneurial ventures, account for most job creation, while Fortune 500 companies have been losing jobs (National Governors Association, 2000b, 2000a). Often operating in fast-paced, quickly changing environments, entrepreneurial ventures maximize their own unique capabilities vis à vis competitors through the maximization and retention of human capital. The human capital of the organization is comprised by the entrepreneurial owner and employees. Entrepreneurial creators feel a strong parent-like attachment to their ventures. However, employees build attachment when they identify with the entrepreneurial 
organization (O'Reilly \& Chatman, 1986). Employee commitment gained through organizational identification represents a powerful way to foster entrepreneurial success.

Empirical research has focused upon entrepreneurial orientation at the firm level, (Miller \& Friesen, 1982; Covin \& Slevin, 1989). The ability to "take calculated risks, be innovative and demonstrate proactiveness" are dimensions of an entrepreneurial orientation (Morris \& Paul, 1987). Miller (Miller, 1983) also defined an entrepreneurial firm as one that is innovating and proactive, and acts in a risk-taking manner. Lumpkin and Dess (1996) agreed but added the dimensions of autonomy and competitive aggressiveness to the other three dimensions. Although human processes and relationships are generally considered to be important firm capabilities (for example, Day \& Wensley, 1988; Day, 1994; Lei, Hitt, \& Bettis, 1996; Dobni \& Luffman, 2000), there has been little discussion of individual level factors that affect entrepreneurial orientation within an individual firm environment. In order to create an entrepreneurial orientation and associated performance outcomes, it is necessary to understand the role of individuals and the interpersonal processes that shape values, norms and behaviors.

Recent research reflects growing interest in the synergies between leadership and entrepreneurship literatures (Cogliser \& Brigham, 2004). Essentially, the purpose of this research is to understand whether an entrepreneurial strategic orientation and a charismatic leadership style encourage employees to identify with the entrepreneurial organization. These variables were chosen because for many small businesses, the strength of the owner's personality and elements of entrepreneurial spirit are important in driving the firm forward in uncertain situations. Also, identification with an organization encourages employees to remain with venture in its crucial growth stages. 


\section{Organizational Identification and Entrepreneurial Orientation}

Identification with the organization is defined as "the perceived oneness with an organization and the experience of the organization's successes and failures as one's own" (Mael \& Ashforth, 1992, p. 103). It predicts important employee attitudes and behaviors, such as pro-social (critical voluntary) work behaviors and employee turnover (O'Reilly \& Chatman, 1986), interpersonal trust, goal-setting processes, and co-operative behaviors (Kramer, 1993; Dutton, Dukerich, \& Harquail, 1994). Employees use the process of identification as they decide how they will behave, and create an opportunity for organizational learning (Kogut \& Zander, 1996). These outcomes represent important reasons for entrepreneurs to build employee identification with the strategy of the entrepreneurial organization.

Entrepreneurial firms generally involve the establishment of a new organization (Shane \& Venkataraman, 2000), exploit new opportunities (Drucker, 1986) and, as Cantillon noted in his early writings on entrepreneurship, function in situations where the expenditures are known but the income is unknown (Hebert \& Link, 1982). These characteristics create an environment where employee commitment is crucial to success. Long hours with no guarantee of success, and potentially delayed financial gratification necessitate employee faith in the entrepreneur and their fledgling business. This faith and commitment is exemplified through employee identification with the entrepreneur.

The strategy of the entrepreneurial organization is reflected in its entrepreneurial orientation (EO) (Child, 1972; Mintzberg, 1973; Miles \& Snow, 1978). Strategically, a firm with an entrepreneurial orientation will take calculated risks, and demonstrate proactiveness and innovation (Miller, 1983; Morris \& Paul, 1987). Additionally, the firm 
will act autonomously (Lumpkin \& Dess, 1996) and take aggressive or assertive actions toward competitors (Miller, 1983; Fredrickson, 1986; Lumpkin \& Dess, 1996).

The strategic orientation of an organization represents the collected values and beliefs of the group of individuals who work in the organization. Although the attitudes and behaviors of both the entrepreneur/owner and employees collectively contribute to the entrepreneurial orientation of the firm, the current business environment has complicated employee retention. Lower job security and employee loyalty has created a situation of increased employee turnover. Employee retention is potentially more important to the success of smaller ventures, where there are fewer employees, and greater expectations of autonomy and versatility. The loss of knowledge resulting from high turnover impedes the steep organizational learning curve experienced by fledgling firms.

Employees of new ventures are often compensated with some form of share ownership because their salaries are lower than comparable jobs in established organizations. Share ownership is a method of compensation that increases employee commitment to the organization. In this atmosphere, employee identification with the firm is important to successful employee retention strategies. However, money is not the only strong motivator in a small business. Employees also remain with entrepreneurial ventures for intrinsic self-motivated reasons related to the challenge of working in an entrepreneurially-oriented company (Pfeffer, 1998).

Hypothesis 1: Employee perceptions of entrepreneurial orientation are positively related to employee organizational identification. 


\section{Organizational Identification and the Quality of the Entrepreneurial Leader}

A successful strategic entrepreneurial orientation is driven in part by the personality and actions of entrepreneurial leaders, as implied by discussions surrounding theories of the firm. For example, the resource-based view of the firm describes the value of entrepreneurial rents (Alvarez \& Busenitz, 2001), and the behavioral theory of the firm discusses the importance of managerial decision-making and actions (Cyert \& March, 1963, 1992).

The word "entrepreneur" is derived from a French word that describes people who provide services (Sexton \& Upton, 1987). According to Cantillon (1755), an entrepreneur directs and redirects resources in the market place, and functions in situations where the expenditures are known but income is unknown. In contrast to the type of situation in which the entrepreneur operates, Schumpeter (1934) described the nature of entrepreneurial activity. Specifically, researchers have described entrepreneurial activity as a "scholarly examination of how, by whom, and with what effects opportunities to create future goods and services are discovered, evaluated and exploited" (Shane \& Venkataraman, 2000, p. 218). It is a "process by which individuals - either on their own or inside organizations - pursue opportunities without regard to the resources they currently control" (Stevenson \& Jarillo, 1990, p. 23). Entrepreneurship may include, but does not require, the creation of a new organization (for example, Casson, 1982; Amit, Glosten, \& Mueller, 1993; Shane \& Venkataraman, 2000; Erikson, 2001).

Other studies have emphasized the importance of both entrepreneurial traits and contextual factors to understanding the concept of entrepreneurship (Olson, 1987; Herron \& Sapienza, 1992; Lau \& Chan, 1994). For example, entrepreneurially-oriented 
individuals embody traits such as risk-taking, proactiveness, and innovativeness (Cauthorn, 1989).

The entrepreneur is often the founder of the organization and a dominant force directing the firm's strategic orientation. The entrepreneurial founder may influence the values underpinning the culture of the organization through the charismatic force of his/her personality. Similarly, previous researchers have commented on the strategic decision-making power of CEOs at the helm of the organization (Sutton \& Staw, 1993; Waldman \& Yammarino, 1999). This strong personality drives the ventures, as entrepreneurs determine the success or failure of their ventures through their commitment and investment.

The industrialists of the $19^{\text {th }}$ and $20^{\text {th }}$ centuries profiled ruthless and often unethical individuals and contrast with a more modern view of an entrepreneur with a strong moral character. For example, a strong sense of values might be demonstrated through support of their local communities, such as the founders of Research in Motion, who donated more than a hundred million dollars to build the Perimeter Institute (an advanced world class facility for the study of physics research) in Waterloo, Canada. This strong moral reasoning and values also profiles a charismatic leader (Turner, Barling, Epitropaki, Butcher, \& Milner, 2002). The similarities between entrepreneurial and charismatic leaders suggest that it is important to study charisma in an entrepreneurial context.

Employees might also choose to remain with entrepreneurial ventures because they are attracted to the convictions and efficacy of the charismatic, entrepreneurial leader. Previous literature has identified an entrepreneurial prototype embodying the need 
for achievement, locus of control, risk-taking, values, and age (Gartner, 1988) comparable to qualities and styles of effective leaders.

Leadership can be viewed as the center of group change, activity and process (Cooley, 1902; Mumford, 1906/1907), as a strength of personality or character (Bowden, 1926; Bingham, 1927) and as a way to influence others toward a common goal (Stogdill, 1950). This influence might be considered a form of persuasion, and related to the use of power and the initiation of structure (Bass, 1990).

Researchers have differentiated effective leaders from managers using a transformational/transactional typology (Burns, 1978). While managers work on a transactional basis, exchanging rewards for job performance, transformational leaders provide employees with meaningful and challenging jobs (Bennis \& Nanus, 1985). The effectiveness of this transformation is driven by the charisma of the leader (Conger, 1989). Weber (1924/1947) and Bass (1990) conceived of charisma to explain why some leaders were considered extraordinary. More recently, implicit leadership research has also supported charisma as a positive attribute of effective leaders (Offermann, Kennedy, \& Wirtz, 1994).

A charismatic leadership style has been identified as important to effective leadership and shares common attributes with entrepreneurial leaders, such as risk-taking and enthusiasm. Previous researchers observed that it is likely that charismatic leadership will flourish in ambiguous and unusual situations (Shamir \& Howell, 1999). Similarly, entrepreneurs flourish during such critical and uncertain markets and must take calculated risks. 
By sharing self-confidence and a vision and purpose, charismatic leaders articulate how followers can meet expected goals (Bass, 1990). Individuals follow charismatic leaders to enhance their self-esteem and self efficacy (Shamir, House, \& Arthur, 1993) and to fulfill higher-order needs (Bass, 1985). Field studies conducted by Conger (1989) identified that followers "often described their strong attraction to the leader's qualities of self-confidence, a strong conviction in the mission, a willingness to undertake personal risks, and their history of prior accomplishments" (Conger, 1999, p. 163). As they seek to win their leader's personal approval, followers feel obligated to live up to the expectations of the leader (Conger, 1999).

In spite of the existence of dissenting views as to whether a charismatic leader must embody "extraordinary qualities", charisma is generally considered to have an element of follower identification with the leader (Yukl, 1999, p. 294). Research in the field of leadership (Weber, 1924/1947; Conger \& Kanungo, 1998; Conger, 1999) indicates that personal identification with the entrepreneur is an important influence mechanism. For example, Conger (1999) suggested that followers may be drawn to charismatic leaders of entrepreneurial companies by both the leader and the challenging opportunity.

An entrepreneurial leader can build unique organizational capabilities by cultivating positive employee perceptions. Employees who believe that the entrepreneur is effective and charismatic will identify with the employer's objectives. In this way, entrepreneurs can retain and "grow" their human capital. Thus, we hypothesize:

Hypothesis 2: Employee perceptions of the strength of the entrepreneur's charisma are positively related to employee organizational identification. 
Hypothesis 3: Employee perceptions of the entrepreneur's effectiveness are positively related to employee organizational identification.

\section{Method}

\section{Sample}

Two hundred and seventy employees from a cross-section of small businesses in South-western Ontario were randomly selected from a sampling frame of businesses with less than 50 employees in an area on-line business directory. The sample included firms from a variety of industry sectors, reflecting the diverse range of services and products provided by small businesses (for example, high tech, manufacturing, food services, consulting). There were 78 usable responses, or a $29 \%$ response rate. The demographics of the sample are shown in Table 1. The sample reflects similar numbers of short-term employees (less than 5 years tenure) and longer-term employees (5 years or more tenure). Although the employee sample reflects a roughly equal split between males and females, the owners are predominantly male.

\section{Data Collection}

An email summarized the objectives and benefits of the research, provided contact information, confirmed that the research adhered to university ethical standards (that is, assuring that it was anonymous and voluntary), and urged potential respondents 
to participate by clicking on a link to the data collection website. Participants entered their responses online and the data were uploaded electronically to a data repository.

Insert Table 1 about here

This method was chosen because previous researchers found that data collection using the Internet results in fewer missing values than paper and pencil data and provides a similar covariance structure (Stanton, 1998). Anonymous web-based data collection safeguards against coercion and forced responses. Other advantages to using web-based technology include lower costs, wider distribution, automated data entry and faster turnaround times (Roztocki \& Morgan, 2002). Response style bias linked to social desirability and shared method bias may result from the collection of self-reported measures. A web-based survey mitigates these biases because participants are presented with only a few items at a time, with constrained ability to move backward.

The survey was pretested with 10 people to ensure that the web-based delivery and data collection system worked well. Further review of the survey by three academics researching in the areas of entrepreneurship and organizational behaviour validated its content.

The survey data were collected on the website over an initial period of two weeks. As the survey response rate was less than $40 \%$, actions were undertaken to eliminate concerns of potential non-response bias (Lambert \& Harrington, 1990). Specifically, the response rate was increased by a follow-up email and telephone call. Wave analysis 
indicated no significant differences between earlier and later responses, and mitigated issues related to low response rate (Creswell, 1994).

\section{Survey Measures}

At the start of the email, respondents were instructed to consider the operating owner or manager of their business when filling out the survey. As these were small businesses, it was reasonable that most of the owners would be actively involved in managing the business (Bygrave, 1994).

Employee perceptions of leader charisma and leader effectiveness were measured using scales developed by Awamleh and Gardner (1999), based on the Multi-factor Leadership Questionnaire (Bass \& Avolio, 1995). Using exploratory factor analysis Awamleh and Gardner collapsed the MLQ items for attributed charisma, idealized influence, inspirational motivation, and effectiveness into two factors of charisma and effectiveness with Cronbach's alphas of .94 and .87 respectively. Both factors are rated on a scale from "Not at all" (0) to "Frequently if not always" (4). A sample charisma item would be "My leader displays a sense of power and confidence". A sample effectiveness item would be "My leader is effective in meeting my job-related needs".

Entrepreneurial orientation was measured using six of eight items from Knight's (1997) scale (Appendix A). Adapted from Covin and Slevin's (1989) entrepreneurship scale, the revision reported a Cronbach's alpha of 0.834. Notably, Covin and Slevin's scale was based upon Miller and Friesen's (1982) slight modification of the original ENTRESCALE (Khandwalla, 1977). This scale attempts to provide an assessment of the degree of entrepreneurial orientation of a given company by considering aspects of innovation and proactiveness. Versions of the ENTRESCALE have been widely used in 
the past to establish entrepreneurial tendencies within a North American context (for example, Khandwalla, 1977) and cross-culturally (Knight, 1997).

The two scale items not included pertained to the number of products introduced into the market, which was more within the knowledge stratosphere of the entrepreneur than of the employee. An additional item, "I consider my leader to be entrepreneurial" was included to validate the entrepreneurial orientation scale.

Organizational identification was measured using O'Reilly and Chatman's (1986) 7 point, three item organizational identification measure. A sample item is "I am proud to tell others that I am a part of this organization”.

\section{Results}

Cronbach's alpha and correlations between the variables are shown in Table 2. All alphas exceeded 0.7, as recommended by Nunnally \& Bernstein (1994). Item-total statistics indicated that all original items contributed to scale reliability. Additionally, the six-item entrepreneurial orientation scale was significantly correlated with the single item entrepreneur validation item $(\mathrm{r}=0.285, \mathrm{p}=.011)$, supporting convergent validity.

The strong and significant correlation between employee perceptions of leader effectiveness and charisma flagged problematic collinearity between the two variables ( $\mathrm{r}$ $=0.903, \mathrm{p}=.000)$. As the sample was not large enough to analyse the data using confirmatory factor analysis, we used exploratory factor analysis (EFA) to understand whether there were specific items from one scale that may load more strongly on the other scale. Although EFA is not generally used with previously developed scales, EFA 
allowed us to revisit the properties of the two scales using a different population and context than the context in which they were originally designed. Maximum likelihood exploratory factor analysis with oblique rotation supported the existence of one factor loading on most of the items from the combined scales (only one item from each scale loaded on a second factor). These results indicated a lack of discriminant validity between the scales. Consequently, leader effectiveness was eliminated from the model.

Insert Table 2 about here

Using accepted statistical methods for testing direct and interaction effects (Cronbach, 1987; Jaccard, Turrisi, \& Wan, 1990; Cohen, 1997), deviation scores were formed by centering the independent variables of entrepreneurial orientation and entrepreneurial charisma. Multiplication of centered variables created an interaction term (entrepreneurial orientation * charisma). Subsequent analysis of correlations between the centered independent and interaction indicates that this resolved issues of multi-collinearity between the independent and interaction variables (Table 3). Research hypotheses were tested by hierarchical regression analysis, by first entering into the equation the centered independent variables of entrepreneurial charisma and entrepreneurial orientation, and second entering the interaction term. Test results of the multiple regression indicate a close fitting regression model, explaining $44 \%$ of the variance in the dependent variable, using normally distributed data.

Regression results (Table 4) indicate significant standardized coefficients and confirm the significant positive relationships between the independent variables and 
dependent variable. However the interaction of entrepreneurial orientation and entrepreneur charisma is not significant. In sum, survey results supported hypothesis one and hypothesis two. However, as noted earlier, the presence of multi-collinearity between entrepreneurial effectiveness and charisma precluded the testing of hypothesis three.

Insert Tables 3 and 4 about here

\section{Discussion}

The results of correlational and exploratory factor analyses indicated that employee perceptions of an entrepreneur's effectiveness and charisma were indistinguishable. Exploratory factor analysis supported the existence of one factor. This finding highlights a potential difference between entrepreneurs and other workplace leaders because it differs from Awamleh and Gardner's (1999) study of leadership, which was able to discriminate between the two constructs. It is likely that the status associated with the term "entrepreneur" also connotes effective leadership. Although this collinearity might be a product of same source bias, the electronic format of the survey tried to mitigate halo effects by presenting scale items randomly and limiting the respondents views of the items to only a few at a time (without the ability to move backward in the survey).

Analysis demonstrated the lack of interaction between the personality of the entrepreneur and the entrepreneurial orientation of the organization when influencing employee organizational identification. This finding indicates that the entrepreneurial 
culture at the senior management level is related to employee outcomes independent of the strong personality of the entrepreneurial owner. Therefore, there is an incentive to developing this strategic orientation at higher levels within an organization.

The study found employee perceptions of the entrepreneurial orientation of the organization positively related to employee identification with the organization. On a practical note, this research explains how charismatic leaders of entrepreneurial firms can retain their employees by stimulating their identification with the organizations. However, not all entrepreneurs may be considered charismatic. Some entrepreneurs may not exhibit the charisma necessary to attract and retain key employees in risky new ventures, but may still be considered entrepreneurial. Indeed, researchers have suggested that to be an entrepreneur does not require a successful business venture (Shane \& Venkataraman, 2000).

Although this research implies that charismatic leadership relates to employee identification, employees may still identify with the entrepreneurial orientation of an organization for other reasons not explained in this model. For example, they may harbour dreams of their own entrepreneurial venture. ${ }^{1}$ Owners may also search out employees that are similar to respective owners in values and attitudes. Finally, previous research has also indicated antecedents of authentic leadership style (including selfawareness, moral values, and positivity) (Avolio, Gardner, Walumbwa, Luthans, \& May, 2004), communication patterns (Wiesenfield, Raghuran, \& Garud, 1999) and the psychological contract (Turnley \& Feldman, 1999). 


\section{Contributions}

This research contributes by enhancing knowledge of successful entrepreneurship and strategy. Empirical results indicated that personality and strategic direction play an important part in creating value for the entrepreneurial firm. Additionally, its individual dimension contributes by combining knowledge of social psychology and strategy.

Study findings increase understanding of potential antecedents of employee organizational identification. This is an outcome of increasing importance in an era of employee increasing mobility and decreasing loyalty. Identification provides a way for entrepreneurs to engage and retain their employees; critical during times of business venture growth and upheaval.

Past research into leader charisma has often used historiometric methodology; that is, a methodology based upon analysis of biographies of famous public and private leaders. This has limited its generalizability for much of the current business situation through topic (usually famous politicians or industry giants are profiled) and through the biased recollection compiled by the biographer. Even the Multi-factor Leadership Questionnaire has generally been used to assess the behaviours of CEOs in large companies. This study extends beyond theories and findings to more common business situations and specifically considers the workings of common entrepreneurial businesses where employees of small businesses know the entrepreneurial owner intimately.

These differing types of relationships necessitate a consideration of levels of analysis, that is, the need to account for variation at both individual and group level of analyses. The level-of-analysis issue at the fore of the leadership literature (for example,

\footnotetext{
${ }^{1}$ We would like to thank an anonymous reviewer for this suggestion.
} 
Schriesheim, Castro, \& Cogliser, 1999; Schriesheim, Castro, Zhou, \& Yammarino, 2001), can be anticipated as an issue in the growing entrepreneurial literature. The current study indicates that there is a rich and untapped field of study that considers interpersonal and individual influences on the success of small businesses.

\section{Limitations and Future Research}

The strong relationships between perceptions of organizational entrepreneurial orientation and organizational identification create the potential for entrepreneurial orientation at the individual employee level. When employees identify with an organization, they are likely to "experience some psychic loss if he or she left the organization” (Mael \& Ashforth, 1992, p. 105). Such a loss to one's psyche or identity might relate to an internalization of entrepreneurial values. This is interesting because it supports the contribution of all employees to strengthening the relationship between entrepreneurial orientation and firm performance.

Future research might develop individual level measures of entrepreneurial orientation for both owners and employees of small businesses. This would foster an understanding of entrepreneurial attitudes and behaviours and how they influence employee commitment and other interpersonal and individual level performance outcomes.

There are some limitations in the interpretation of results. Employee perceptions of the independent and dependent variables were measured using the same instrument. This presents the potential for same source bias in the results. Future research would be strengthened by measuring the dependent and independent variables at different times, using different instruments. 
The study design (a unsolicited internet survey) precluded the collection of objective performance data. Thus, this study collected data regarding the perceptions of employees. Additionally, future research must collect information as to leader effectiveness or entrepreneurial orientation using more objective measures such as performance benchmarks. This would eliminate potential same source bias. Finally, there is a need to replicate these results with a larger sample across a wider geographical area.

\section{Conclusion}

This study presents an explanation of individual and organizational level mechanisms supporting an effective entrepreneurial orientation. Employee perceptions of the entrepreneur's personality and the entrepreneurial orientation of the organization are important influences on employee organizational identification. This conceptual and empirical development fills a gap in the emerging field of entrepreneurship. As entrepreneurship becomes a recognized business field, it must build upon knowledge and research from more established literature in other business-related fields such as social psychology. Entrepreneurs may be absorbed by strategic and financial issues, but this research emphasizes the importance of managing employee perceptions. It demonstrates the full power of an entrepreneur's personality, and contributes to our knowledge of why some entrepreneurial ventures succeed, while others do not. 


\section{References}

Alvarez, S. A., \& Busenitz, L. W. (2001). "The Entrepreneurship of Resource-Based Theory." Journal of Management, 27(6), 755-775.

Amit, R., Glosten, L., \& Mueller, E. (1993). "Challenges to Theory Development in Entrepreneurship Research." Journal of Management Studies, 30, 815-834.

Avolio, B. J., Gardner, W. L., Walumbwa, F. O., Luthans, F., \& May, D. R. (2004). "Unlocking the Mask: A Look at the Process by Which Authentic Leaders Impact Follower Attitudes and Behaviors." Leadership Quarterly, 15(6), 801-823.

Awamleh, R., \& Gardner, W. (1999). "Perceptions of Leader Charisma and Effectiveness: The Effects of Vision Content, Delivery and Organizational Performance." Leadership Quarterly, 10(3), 345-373.

Bass, B. M. (1985). Leadership and Performance Beyond Expectations. New York: Free Press.

Bass, B. M. (1990). Bass \& Stogdill's Handbook of Leadership. New York: The Free Press.

Bass, B. M., \& Avolio, B. J. (1995). Manual for the Multifactor Leadership Questionnaire: Rater Form (5x Short). Palo Alto, CA: Mind Garden.

Bennis, W., \& Nanus, B. (1985). Leaders: The Strategies for Taking Charge. New York: Harper \& Row.

Bingham, W. (1927). "Leadership." (In H. Metcalf (Ed.), The Psychological Foundations of Management. New York: Shaw.

Bowden, A. (1926). "A Study of the Personality of Student Leaders in the United States." Journal of Abnormal and Social Psychology(47), 534-539.

Burns, J. (1978). Leadership. New York: Harper \& Row.

Bygrave, W. D. (1994). The Portable M.B.A. In Entrepreneurship. New York: John Wiley and Sons.

Cantillon, R. (1755). Essai Sur La Nature Du Commerce En General. London: MacMillan.

Casson, M. (1982). The Entrepreneur : An Economic Theory /: Oxford : Martin Robertson,.

Cauthorn, R. C. (1989). Contributions to a Theory of Entrepreneurship. New York: Garland Publishing.

Child, J. (1972). "Organization Structure and Strategies of Control - a Replication of the Ashton Study." Administrative Science Quarterly, 17(2), 163.

Cogliser, C., \& Brigham, K. (2004). "The Intersection of Leadership and Entrepreneurship: Mutual Lessons to Be Learned." The Leadership Quarterly, 15, 771-799.

Cohen, A. (1997). "Nonwork Influences on Withdrawal Cognitions: An Empirical Examination of an Overlooked Issue." Human Relations, 50(12), 1511-1536.

Conger, J. (1989). The Charismatic Leader: Behind the Mystique of Exceptional Leadership. San Francisco: Jossey-Bass.

Conger, J. (1999). "Charismatic and Transformational Leadership in Organizations: An Insider's Perspective on These Developing Streams of Research." Leadership Quarterly, 10(2), 145-179. 
Conger, J. A., \& Kanungo, R. N. (1998). Charismatic Leadership in Organizations. Thousand Oaks: Sage.

Cooley, C. (1902). Human Nature and the Social Order. New York: Scribners.

Covin, J., \& Slevin, D. (1989). "Strategic Management of Small Firms in Hostile an Benign Environments." Strategic Management Journal, 10(1), 75-88.

Creswell, J. W. (1994). Research Design: Qualitative and Quantitative Approaches. Thousand Oaks: Sage Publications.

Cronbach, L. J. (1987). "Statistical Tests for Moderator Variables: Flaws in Analysis Recently Proposed." Psychological Bulletin, 102, 414-417.

Cyert, R. M., \& March, J. G. (1963, 1992). A Behavioral Theory of the Firm (Second ed.). Cambridge, Mass: Blackwell Publishers.

Day, G. S. (1994). "The Capabilities of Market-Driven Organizations." Journal of Marketing, 58(4), 37-53.

Day, G. S., \& Wensley, R. (1988). "Assessing Advantage: A Framework for Diagnosing Competitive Superiority." Journal of Marketing, 52(April), 1-20.

Dobni, C. B., \& Luffman, G. (2000). "Implementing a Marketing Strategy through a Market Orientation." Journal of Marketing Management, 16, 895-916.

Drucker, P. (1986). "Innovation Is in the Air." Modern Office Technology, 31(3), 12-15.

Dutton, J. E., Dukerich, J. M., \& Harquail, C. V. (1994). "Organizational Images and Member Identification." Administrative Science Quarterly, 39, 239-263.

Erikson, T. (2001). "'the Promise of Entrepreneurship as a Field of Research": A Few Comments and Some Suggested Extensions." Academy of Management, 26(1), 12-13.

Fredrickson, J. W. (1986). "The Strategic Decision Process and Organizational Structure." Academy of Management Executive, 11(2), 280-298.

Gartner, B. W. (1988). "'Who Is an Entrepreneur?" Is the Wrong Question." American Journal of Small Business, 88, 11-32.

Hebert, R., \& Link, A. (1982). The Entrepreneur. New York, NY: Preager.

Herron, L., \& Sapienza, H. J. (1992). "The Entrepreneur and the Initiation of New Venture Launch Activities." Entrepreneurship Theory and Practice, 17(1), 49-56.

Jaccard, J., Turrisi, R., \& Wan, C. K. (1990). Interaction Effects in Multiple Regression (Vol. 07-072). Newbury Park, CA: SAGE Publications, Inc.

Khandwalla, P. N. (1977). The Design of Organizations. New York, New York: Harcourt Brace Jovanovich, Inc.

Knight, G. (1997). "Cross-Cultural Reliability and Validity of a Scale to Measure Firm Entrepreneurial Orientation." Journal of Business Venturing, 12(3), 213-225.

Kogut, B., \& Zander, R. (1996). "What Firms Do? Coordination, Identity and Learning." Organization Science, 7, 502-518.

Kramer, R. M. (1993). "Cooperation and Organizational Identification." (In J. K. Murnighan (Ed.), Social Psychology in Organizations: Advances in Theory and Research. Englewood Cliffs, NJ: Prentice-Hall.

Lambert, D. M., \& Harrington, T. C. (1990). "Measuring Nonresponse Bias in Customer Service Mail Surveys." Journal of Business Logistics, 11(2), 5-25.

Lau, T., \& Chan, K. F. (1994). "The Incident Method - an Alternative Way of Studying Entrepreneurial Behaviour." IBAR, 15, 48-62. 
Lei, D., Hitt, M. A., \& Bettis, R. (1996). "Dynamic Core Competences through MetaLearning and Strategic Context." Journal of Management Consulting, 22(4), 549570.

Lumpkin, G. T., \& Dess, G. G. (1996). "Clarifying the Entrepreneurial Orientation Construct and Linking It to Performance." Academy of Management Executive, 21(1), 135-173.

Mael, F., \& Ashforth, B. E. (1992). "Alumni and Their Alma Mater: A Partial Test of the Reformulated Model of Organizational Identification." Journal of Organizational Behavior, 13, 103-123.

Miles, R. E., \& Snow, C. C. (1978). Organizational Strategy, Structure, and Process. Toronto: McGraw-Hill Book Company.

Miller, D. (1983). "The Correlates of Entrepreneurship in Three Types of Firms." Management Science, 29(7), 770-792.

Miller, D., \& Friesen, P. H. (1982). "Innovation in Conservative and Entrepreneurial Firms: Two Models of Strategic Momentum." Strategic Management Journal, $3(1), 1-25$.

Mintzberg, H. (1973). The Nature of Managerial Work. New York: Harper \& Row.

Morris, M. H., \& Paul, G. W. (1987). "The Relationship between Entrepreneurship and Marketing in Established Firms." Journal of Business Venturing, 2(3), 247-260.

Mumford, E. (1906/1907). "Origins of Leadership." American Journal of Sociology, 12, 216-240.

National Governors Association. (2000a). Building State Economies by Promoting University - Industry Technology Transfer. Washington, D.C.: National Governors Association.

National Governors Association. (2000b). Nurturing Entrepreneurial Growth in State Economies. Washington, D.C.: National Governors Association.

Nunnally, J., \& Bernstein, Î. (1994). Psychometric Theory. New York: McGraw-Hill.

Offermann, L., Kennedy, J., \& Wirtz, P. (1994). "Implicit Leadership Theories: Content, Structure and Generalizability." Leadership Quarterly, 5(1), 43-58.

Olson, P. D. (1987). "Entrepreneurship and Management." Journal of Small Business Management, 25(3), 7-14.

O'Reilly, C., \& Chatman, J. (1986). "Organizational Commitment and Psychological Attachment: The Effect of Compliance, Identification, and Internalization on Prosocial Behavior." Journal of Applied Psychology, 71(3), 492-499.

Pfeffer, J. (1998). The Human Equation Building Profits by Putting People First. Boston: Harvard Business School Press.

Roztocki, N., \& Morgan, S. D. (2002). The Use of Web-Based Surveys for Academic Research in the Field of Engineering. Paper presented at the American Society of Engineering Management (ASEM) National Conference.

Schriesheim, C. A., Castro, S. L., \& Cogliser, C. C. (1999). "Leader-Member Exchange (Lmx) Research: A Comprehensive Review of Theory, Measurement and DataAnalytic Practices." Leadership Quarterly, 10(1), 63-113.

Schriesheim, C. A., Castro, S. L., Zhou, X. T., \& Yammarino, F. (2001). "The Folly of Theorizing "a"but Testing "B": A Selective Level-of-Analysis Review of the Field and a Detailed Leader-Member Exchange Illustration." Leadership Quarterly, 12, 515-551. 
Schumpeter, J. A. (1934). The Theory of Economic Development (O. R., Trans. 7th ed. ed.). Cambridge, MA: Harvard University Press.

Sexton, D. L., \& Upton, N. B. (1987). "Evaluation of an Innovative Approach to Teaching Entrepreneurship." Journal of Small Business Management, 25(1), 35 44.

Shamir, B., House, R., \& Arthur, M. (1993). "The Motivation Effects of Charismatic Leadership a Self-Concept Based Theory." Organization Science, 4, 584.

Shamir, B., \& Howell, J. M. (1999). "Organizational and Contextual Influences on the Emergence and Effectiveness of Charismatic Leadership." Leadership Quarterly, 10(2).

Shane, S., \& Venkataraman, S. (2000). "The Promise of Entrepreneurship as a Field of Research." Academy of Management Executive, 25(1), 217-226.

Stanton, J. M. (1998). "An Empirical Assessment of Data Collection Using the Internet." Personnel Psychology, 51, 709-725.

Stevenson, H. H., \& Jarillo, J. C. (1990). "A Paradigm of Entrepreneurship: Entrepreneurial Management." Strategic Management Journal, 11, 17-28.

Stogdill, R. (1950). "Leadership, Membership and Organization." Psychological Bulletin, 47, $1-14$.

Sutton, R., \& Staw, B. M. (1993). "Macro Organizational Psychology." (In J. K. Murnighan (Ed.), Social Psychology in Organizations: Advances in Theory and Research (pp. 350-384). Englewood Cliffs, NJ: Prentice-Hall.

Turner, J., Barling, J., Epitropaki, O., Butcher, V., \& Milner, C. (2002). "Transformational Leadership and Moral Reasoning." Journal of Applied Psychology, 87(2), 304-311.

Turnley, W. H., \& Feldman, D. C. (1999). "A Discrepancy Model of Psychological Contract Violations." Human Resource Management Review, 9(3), 367-386.

Waldman, D. A., \& Yammarino, F. (1999). "Ceo Charismatic Leadership: Levels-ofManagement and Levels-of-Analysis Effects." Academy of Management Review, 24(2), 266-285.

Weber, M. (1924/1947). The Theory of Social and Economic Organization. New York: Free Press.

Wiesenfield, B. M., Raghuran, S., \& Garud, R. (1999). "Communication Patterns as Determinants of Organizational Identification in a Virtual Organization." Organization Science, 10(6), 777-790.

Yukl, G. (1999). "An Evaluation of Conceptual Weaknesses in Transformational and Charismatic Leadership Theories." Leadership Quarterly, 10(2), 285-305. 


\section{Table 1}

Study Demographics

\begin{tabular}{cl}
\hline Sample Size & $\mathrm{N}=78$ \\
Employee Age & $0-$ Under 20 \\
& $20-20-29$ \\
& $33-30-39$ \\
& $20-40-49$ \\
& $5-50-59$ \\
& $0-60+$ \\
Employee Gender & 38 Male \\
& 40 Female \\
& 66 Male \\
Leader Gender & 12 Female \\
& $12-$ Less than 1 year \\
& $27-1$ year to less than 5 years \\
Years Employed & $17-5$ years to less than 10 years \\
& $22-10$ years or more \\
\hline
\end{tabular}


Table 2

\section{Correlations and Reliability Statistics}

\begin{tabular}{|c|c|c|c|c|c|c|}
\hline & Alpha & & 1 & 2 & 3 & 4 \\
\hline $\begin{array}{l}\text { 1. Entrepreneurial } \\
\text { Orientation }\end{array}$ & .75 & $\begin{array}{l}\text { Pearson } \\
\text { Correlation }\end{array}$ & 1 & & & \\
\hline $\begin{array}{l}\text { 2. Organizational } \\
\text { Identification }\end{array}$ & .85 & $\begin{array}{l}\text { Pearson } \\
\text { Correlation }\end{array}$ & $.546(* *)$ & 1 & & \\
\hline $\begin{array}{c}\text { 3. Entrepreneurial } \\
\text { Charisma }\end{array}$ & .94 & $\begin{array}{l}\text { Pearson } \\
\text { Correlation }\end{array}$ & $.527(* *)$ & $.647(* *)$ & 1 & \\
\hline $\begin{array}{l}\text { 4. Entrepreneurial } \\
\text { Effectiveness }\end{array}$ & .93 & $\begin{array}{l}\text { Pearson } \\
\text { Correlation }\end{array}$ & $.535(* *)$ & $.672(* *)$ & $.906(* *)$ & 1 \\
\hline
\end{tabular}

** Correlation is significant at the 0.01 level (1-tailed). 
Table 3

\section{Correlations for Centered Independent and Interaction Variables}

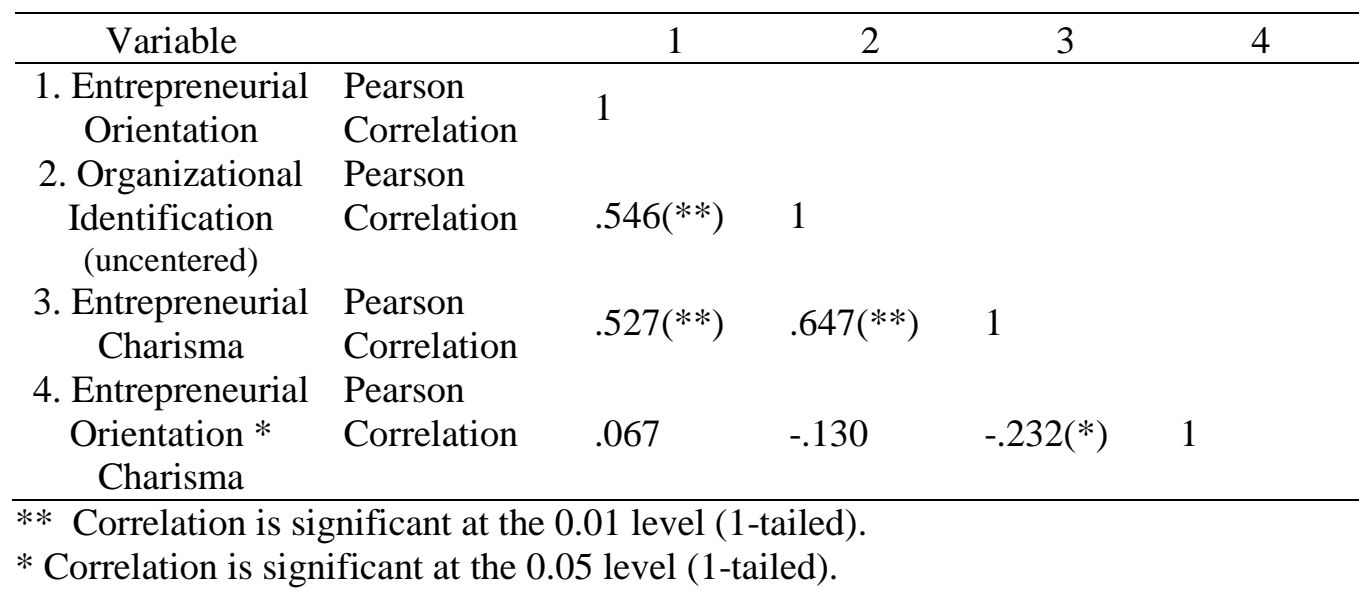


Table 4

\section{Hierarchical Regression Results (Standardized Coefficents)}

\begin{tabular}{llll}
\hline & \multicolumn{3}{c}{ Organizational Identification } \\
\cline { 2 - 4 } Variables & Step 1 & Step 2 & Step 3 \\
\hline Independent Variables & & & \\
$\quad$ Entrepreneurial Charisma & $.622^{* * *}$ & $.454 * * *$ & $.435^{* *}$ \\
$\quad$ Entrepreneurial Orientation & & $.318^{* *}$ & $.332^{* *}$ \\
Interaction & & & \\
$\quad$ Entrepreneurial Orientation x Charisma & & & .052 \\
$R^{2}$ & .386 & .46 & .462 \\
Adjusted $R^{2}$ & .376 & .441 & .433 \\
F Change & $36.534 * * *$ & $7.707 * *$ & .249 \\
\hline$* * \mathrm{p} \leq .01$ & & & \\
$* * * \mathrm{p} \leq .001$ & & &
\end{tabular}




\section{Appendix A}

\section{Measure of Entrepreneurial Orientation}

\begin{tabular}{|c|c|c|c|c|c|c|c|}
\hline \multicolumn{8}{|c|}{ In general top managers in this firm favour... } \\
\hline $\begin{array}{l}\text { A strong emphasis on } \\
\text { the marketing of tried } \\
\text { and true products and } \\
\text { services }\end{array}$ & $\leftarrow$ & $\diamond$ & $\diamond$ & $\diamond$ & $\diamond$ & $\diamond \diamond$ & $\begin{array}{l}\text { A strong emphasis on } \\
\text { R\&D technological } \\
\text { leadership and innovations }\end{array}$ \\
\hline \multicolumn{8}{|c|}{ In dealing with competitors this firm... } \\
\hline $\begin{array}{l}\text { Is very seldom the first } \\
\text { business to introduce } \\
\text { new product/services } \\
\text { administrative } \\
\text { techniques operating } \\
\text { technologies etc. }\end{array}$ & $\leftarrow$ & $\diamond$ & $\diamond$ & $\diamond$ & $\diamond$ & $\diamond \diamond$ & $\begin{array}{l}\text { Is very often the first } \\
\text { business to introduce new } \\
\text { roducts/services } \\
\text { administrative techniques } \\
\text { operating technologies etc. }\end{array}$ \\
\hline \multicolumn{8}{|c|}{ In dealing with competitors this firm... } \\
\hline $\begin{array}{l}\text { Typically adopts a } \\
\text { very } \\
\text { competitive"undo-the- } \\
\text { competitors" posture }\end{array}$ & $\leftarrow$ & $\diamond$ & $\diamond$ & $\diamond$ & $\diamond$ & $--\rightarrow$ & $\begin{array}{l}\text { Typically seeks to avoid } \\
\text { competitive clashes } \\
\text { preferring a "live and let } \\
\text { live" posture }\end{array}$ \\
\hline \multicolumn{8}{|c|}{ In general the top managers at this firm... } \\
\hline $\begin{array}{l}\text { Tend to prefer high- } \\
\text { risk projects (with } \\
\text { chances of very high } \\
\text { return) }\end{array}$ & $\leftarrow$ & $\diamond$ & $\diamond$ & $\diamond$ & $\diamond$ & 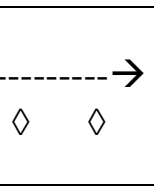 & $\begin{array}{l}\text { Tend to prefer low-risk } \\
\text { projects (with normal and } \\
\text { certain rates of return) }\end{array}$ \\
\hline \multicolumn{8}{|c|}{ When confronted with decision-making situations involving uncertainty this firm... } \\
\hline $\begin{array}{l}\text { Typically adopts a } \\
\text { "wait-and-see" posture } \\
\text { in order to minimize } \\
\text { the probability of } \\
\text { making costly } \\
\text { decisions }\end{array}$ & $\leftarrow$ & $\diamond$ & $\diamond$ & $\diamond$ & $\diamond$ & $\diamond$ & $\begin{array}{l}\text { Typically adopts a bold } \\
\text { aggressive posture in order } \\
\text { to maximize the } \\
\text { probability of exploiting } \\
\text { potential opportunities. }\end{array}$ \\
\hline \multicolumn{8}{|c|}{ In general the top managers at this firm... } \\
\hline $\begin{array}{l}\text { Believe that owing to } \\
\text { the nature of the } \\
\text { environment it's best to } \\
\text { explore it gradually via } \\
\text { careful incremental } \\
\text { behavior }\end{array}$ & $\leftarrow$ & $\diamond$ & $\diamond$ & $\diamond$ & $\diamond$ & $--\rightarrow$ & $\begin{array}{l}\text { Believe that owing to the } \\
\text { nature of the environment } \\
\text { bold wide-ranging acts are } \\
\text { necessary to achieve the } \\
\text { firm's objectives }\end{array}$ \\
\hline
\end{tabular}

